\title{
GMR
}

\section{Association of RUNX2 and TNFSF11 genes with production traits in a paternal broiler line}

\author{
N.V. Grupioni ${ }^{1}$, N.B. Stafuzza ${ }^{1}$, A.B. Carvajal $^{1}$, A.M.G. Ibelli ${ }^{2}$, J.O. Peixoto ${ }^{2}$, \\ M.C. Ledur ${ }^{2}$ and D.P. Munari ${ }^{1}$ \\ ${ }^{1}$ Departamento de Ciências Exatas, Faculdade de Ciências Agrárias e Veterinárias, \\ Universidade Estadual Paulista, Jaboticabal, SP, Brasil \\ ${ }^{2}$ Embrapa Suínos e Aves, Concórdia, SC, Brasil \\ Corresponding author: D.P. Munari \\ E-mail: danisio@fcav.unesp.br
}

Genet. Mol. Res. 16 (1): gmr16019443

Received October 18, 2016

Accepted December 19, 2016

Published March 22, 2017

DOI http://dx.doi.org/10.4238/gmr16019443

Copyright $(2017$ The Authors. This is an open-access article distributed under the terms of the Creative Commons Attribution ShareAlike (CC BY-SA) 4.0 License.

\begin{abstract}
Intense selection for production traits has improved the genetic gain of important economic traits. However, selection for performance and carcass traits has led to the onset of locomotors problems and decreasing bone strength in broilers. Thus, genes associated with bone integrity traits have become candidates for genetic studies in order to reduce the impact of bone disorders in broilers. This study investigated the association of the RUNX2 and TNFSF11 genes with 79 traits related to performance, carcass composition, organs, and bone integrity in a paternal broiler line. Analyses of genetic association between single-nucleotide polymorphisms (SNPs) and traits were carried out using the maximum likelihood procedures for mixed models. Genetic associations $(\mathrm{P}<0.05)$ were found between SNP g. 124,883A>G in the RUNX2 gene and chilled femur weight (additive plus dominance deviation effects within sex) and with performance traits (additive within sex and additive effects). The SNP g. 14,862T $>C$ in the TNFSF11 gene presented genetic associations $(\mathrm{P}<0.05)$ with additive plus dominance deviation effects within sex for performance
\end{abstract}

Genetics and Molecular Research 16 (1): gmr16019443 
traits. Suggestive genetic associations $(\mathrm{P}<0.10)$ were found with abdominal fat and its yield. Selection based on SNPs g.14,862T>C in TNFSF11 and g.124,883A>G in RUNX2 could be used to improve performance and carcass quality traits in the population studied, although SNP g. 14,862T $>C$ was not in Hardy-Weinberg equilibrium because it was not undergoing a selection process. Furthermore, it is important to validate these markers in an unrelated population for use in the selection process.

Key words: Body weight; Bone integrity; Femur; PCR-RFLP; SNP

\section{INTRODUCTION}

Intense selection for phenotypic traits in broilers has resulted in genetic improvement for rapid growth and meat yield (Dransfield and Sosnicki, 1999; Li et al., 2003). However, it has had a negative impact on the skeletal structure in broilers, because animals with high growth rates do not present a skeletal structure strong enough to support their body weight (Ragognetti et al., 2015). Animals with a fast growth rate exhibit decreased locomotor activity and spend more time sitting or lying down (Bessei, 2006). Thus, the incidence of bone disorder-related problems has also increased, because bone development requires more time than the rapid body growth allows. According to Julian (1998), high nutrient intake induces rapid growth and results in bone disorders and severe lameness. Furthermore, the same author pointed out that musculoskeletal disorders may be caused by rapid growth and that defects could be related to high body weight, immature bone tissues, insufficient time to produce strong bone tissues, high specific nutrient requirements, and increase of metabolic products. Fractures such as osteoporosis can result in serious animal welfare concerns because they cause acute and chronic pain as well as mortality (Danbury et al., 2000). It is necessary to better understand problems related to bone integrity because they contribute to increased mortality and carcass condemnations and reduce productivity (Rath et al., 2000).

Animal skeletal development can be influenced by genes involved in growth rates (Zhou et al., 2005; Locatelli and Bianchi, 2014), which can be observed through genetic correlations between weight, weight gain, and bone integrity traits and can be manipulated through selection (Lamont et al., 2004; González-Cerón et al., 2015). Grupioni et al. (2015) found that the breaking strength resistance of the femur is highly genetically correlated with mineral content in a TT Reference Population of broilers. Da Cruz et al. (2015) observed significant associations $(\mathrm{P}<0.05)$ of single-nucleotide polymorphism $(\mathrm{SNP}) g .729 C>T$ of the ADIPOR 1 (adiponectin receptor 1) gene with bone integrity traits and breast skin yield in the same population of broilers, suggesting that this gene can act in metabolism, fat deposition, and bone integrity. Fornari et al. (2014) found that the SNP g.9144C $>G$ in the TNFRSF11B (osteoprotegerin) gene was associated with skeletal structure, performance, and carcass traits in the TT Reference Population of broilers. Genetic associations were also found between the ACTA1 (actin, alpha1, skeletal muscle) gene and performance and carcass traits in the same population (Venturini et al., 2015).

Association studies of candidate genes functionally related to bone integrity may help to identify markers that can be used in genetic selection for traits related to bone strength, in order to reduce bone disorders resulting from the intense selection process for broiler growth

Genetics and Molecular Research 16 (1): gmr16019443 
(Zhou et al., 2007). The runt-related transcription factor 2 gene $(R U N X 2)$ is a potential candidate for the study of bone integrity-related traits since it is involved in bone tissue development and maintenance, acting as a transcription factor in osteoblast formation (Kammerer et al., 2013). Mutations in RUNX2 can cause diseases such as cleidocranial dysplasia (Otto et al., 2002), which primarily affects the skeletal system, resulting in membranous bones and endochondral ossification, which may be categorized as a generalized disorder of the skeletal structure (Neville et al., 2002).

The tumor necrosis factor (ligand) superfamily member 11 gene (TNFSF11), also known as receptor activator of nuclear factor- $\mathrm{BB}$ ligand (RANKL) (Boyle et al., 2003), plays an important role in the regulation of the bone remodeling process (Genetics and Home Reference, 2013), acting on osteoclast differentiation and expression, the function of which is to reabsorb the mineralized bone matrix (Usui et al., 2008).

Association studies of these two genes with meat production and bone integrity traits in broiler lines are important, especially for skeletal structure, because these traits are difficult to measure and have low genetic gains, since they have low to moderate heritability estimates (Grupioni et al., 2015) and require the slaughter of animals for data collection. Hence, the aim of this study was to investigate the association of polymorphisms in the RUNX2 and TNFSF11 genes with performance, carcass composition, organs, and bone integrity-related traits in a paternal broiler line.

\section{MATERIAL AND METHODS}

\section{Ethics statement}

This study was approved by the Embrapa Swine and Poultry Ethical Committee for Animal Use (CEUA) under protocol number 011/2011, following international guidelines for animal welfare.

\section{Experimental population and phenotypic traits}

The TT Reference Population database used in this study belongs to the Embrapa Swine and Poultry National Research Center, Concordia, SC, Brazil. The TT Reference Population is a paternal broiler line originating from the crossing of Cornish, Hampshire, and White Plymouth Rock breeds, which was formed from the expansion of the pure line of broilers by mating 20 males with 92 females (1:5) in 5 hatches, resulting in about 1,500 progeny. Selection of this broiler line has been performed since 1992 in order to increase body weight and carcass traits, decrease abdominal fat percentage, and improve reproductive traits and feed conversion rates (da Cruz et al., 2015).

The chicks were tagged with metal rings for pedigree control at birth. The broilers were kept in collective boxes until 35 days of age, and from 35 to 41 days they were housed in individual cages to allow the evaluation of feed conversion. Diets consisted of $3150 \mathrm{kcal} / \mathrm{kg}$ metabolizable energy (ME) and $21 \%$ crude protein (CP) from 1 to 21 days, $3200 \mathrm{kcal} / \mathrm{kg} \mathrm{ME}$ and $20 \% \mathrm{CP}$ from 22 to 34 days, and $3200 \mathrm{kcal} / \mathrm{kg} \mathrm{ME}$ and $18.5 \% \mathrm{CP}$ from 35 to 41 days of age.

Broilers were slaughtered at 42 days of age and $2 \mathrm{~mL}$ blood was collected during bleeding from the jugular and stored in $2 \mathrm{~mL}$ microtubes containing $100 \mu \mathrm{L}(10 \% \mathrm{v} / \mathrm{v}) 0.5 \mathrm{M}$ EDTA anticoagulant for DNA extraction. A total of 79 traits from the TT Reference Population

Genetics and Molecular Research 16 (1): gmr16019443 
database were evaluated, including traits related to broiler performance, carcass composition, organs, and bone integrity (see Table S1). The descriptive statistics of those traits were described by Fornari et al. (2014).

The methodology used to determine bone dry matter percentage, ashes, and mineral content was previously described by Grupioni et al. (2015). These analyses were performed at the Physical-Chemical Laboratory at Embrapa Swine and Poultry, Concordia, SC, Brazil.

\section{Extraction and quantification of DNA samples}

Genomic DNA was extracted using the DNA extraction protocol with DNAzol ${ }^{\mathbb{}}$ reagent (Invitrogen). A total of $500 \mu \mathrm{L} \mathrm{DNAzol}{ }^{\circledR}$ was added to $15 \mu \mathrm{L}$ whole blood stored in $0.5 \mathrm{M}$ EDTA and homogenized. About $500 \mu \mathrm{L}$ of absolute ethanol was added to the tubes and mixed gently several times. The precipitate was removed and placed in another tube using a micropipette and washed in $1 \mathrm{~mL} \mathrm{95 \%}$ ethanol. Samples were centrifuged at $3500 \mathrm{~g}$ for $10 \mathrm{~min}$, washed in $1 \mathrm{~mL} \mathrm{75 \%}$ ethanol, and centrifuged under the same conditions. Next, the supernatant was discarded and the pellet dried at $22^{\circ} \mathrm{C}$ for $30 \mathrm{~min}$. The DNA was re-suspended in $150 \mu \mathrm{L}$ ultra-pure water, incubated at $37^{\circ} \mathrm{C}$ for $1 \mathrm{~h}$ in a water bath and stored at $-20^{\circ} \mathrm{C}$ until use. DNA integrity was verified using $1 \%$ agarose gel stained with ethidium bromide and quantified in a BioPhotometer ${ }^{\mathrm{TM}}$ (Eppendorf, Hamburg, Germany) spectrophotometer. The concentrations of the samples were adjusted to $25 \mathrm{ng} / \mu \mathrm{L}$.

\section{Amplification and genotyping by PCR-RFLP}

Sequence information regarding the RUNX2 and TNFSF11 genes was retrieved from the NCBI database (http://www.ncbi.nlm.nih.gov) using the genome annotation Reference Gallus gallus-5.0 Primary Assembly. RUNX2 presents a total of 214,603 bp, located on chromosome 3 between 109,768,999 and 109,983,601 bp (gene ID: 373919, updated on 5 Jan 2016). TNFSF11 contains a total of $22,682 \mathrm{bp}$, located on chromosome 1 between 166,505,163 and 166,527,844 bp (gene ID: 428067, updated on 5 Jan 2016). The PCR primers were designed using Primer3Plus software (Untergasser et al., 2007) (see Table S2).

To amplify the target DNA of RUNX2 and TNFSF11, PCR reactions were standardized as follows: $50 \mathrm{ng}$ genomic DNA was added to a reaction mix composed of $1 \mathrm{X}$ buffer (10X High Fidelity buffer $\left[600 \mathrm{mM}\right.$ Tris-SO $\left.\left.{ }_{4}(\mathrm{pH} 8.9), 180 \mathrm{mM}\left(\mathrm{NH}_{4}\right)_{2} \mathrm{SO}_{4}\right]\right), 1 \mu \mathrm{L} \mathrm{MgSO}_{4}(50$ $\mathrm{mM}), 0.4 \mathrm{mM} \mathrm{dNTP}, 0.2 \mathrm{mM}$ each primer, and $1 \mathrm{U}$ Platinum Taq DNA Polymerase High Fidelity (Invitrogen), for a total final volume of $25 \mu \mathrm{L}$.

The amplifications were carried out under the following conditions: initial denaturation for $5 \mathrm{~min}$ at $95^{\circ} \mathrm{C}$, followed by 35 cycles of denaturation for $1 \mathrm{~min}$ at $95^{\circ} \mathrm{C}, 60^{\circ} \mathrm{C}$ for $1 \mathrm{~min}$ (annealing), extension at $72^{\circ} \mathrm{C}$ for $1 \mathrm{~min}$, and a final extension at $72^{\circ} \mathrm{C}$ for $10 \mathrm{~min}$. The restriction enzymes that recognize specific SNP sites were selected using NEBcutter software (Vincze et al., 2003). The HinfI (5' G $\left.\downarrow A N T C 3^{\prime}\right)$ and BtsCI (5' GGATGNN $\downarrow$ 3') restriction enzymes were used to genotype the SNPs of TNFSF 11 and RUNX2, respectively. The SNPs evaluated were submitted to dbSNP (http://www.ncbi.nlm.nih.gov/snp), under accession number ss 1966531575 for the SNP g. 14,862T>C located in the TNFSF11 gene and ss 1966531593 for the SNP $g .124,883 A>\mathrm{G}$ in the $R U N X 2$ gene. For RFLP analysis, $10 \mu \mathrm{L}$ of the PCR reaction was performed using $5 \mu \mathrm{L}$ PCR products, $1 \mathrm{U}$ restriction enzyme, and $1 \mathrm{X}$ enzyme buffer. The digestion occurred overnight at $37^{\circ} \mathrm{C}$ and $50^{\circ} \mathrm{C}$ for $\mathrm{HinfI}$ and $\mathrm{Bts} \mathrm{CI}$ restriction enzymes, respectively.

Genetics and Molecular Research 16 (1): gmr16019443 
The PCR-RFLP products were visualized on $2 \%$ agarose gels stained with ethidium bromide, submitted to electric current at $80 \mathrm{~V}$ for $120 \mathrm{~min}$ in $1 \mathrm{X}$ TBE buffer, and analyzed in a transluminator under UV light. To identify the size of the amplified fragments, a $100 \mathrm{bp}$ molecular marker (Invitrogen) was used.

\section{Statistical analysis}

Genotypic frequency analyses were performed using the SAS FREQ procedure (Statistical Analysis System, v.9.3, Cary, NC). Hardy-Weinberg equilibrium was tested for each SNP using the chi-square $\left(\chi^{2}\right)$ test with 1 degree of freedom at the $5 \%$ significance level $(\mathrm{P}<0.05)$.

The association analyses between SNPs and phenotypic traits were performed using QxPak v. 4.1 software (Pérez-Enciso and Misztal, 2004), which uses maximum likelihood procedures for mixed models through the following general linear model:

$$
y_{i j k l m}=m+H_{i}+S_{k}+S N P_{i}+a_{i j k l m}+e_{i j k l m} \quad \text { (Equation 1) }
$$

where $y_{i k k l m}$ is the record of the phenotypic trait; $\mu$ is the trait's overall mean; $H_{i}$, is the fixed effect of the $i^{\text {th }}$ hatch (with $i=1 \ldots 5$ ); $\mathrm{S}_{\mathrm{k}}$ is the fixed effect of the $k^{\text {th }} \operatorname{sex}(k=1,2) ; \mathrm{SNP}_{l}$ is the fixed effect of the $l^{\text {th }}$ genotype $(l=11,12,22) ; a_{i j k l m}$ is the random effect of the $j^{\text {th }}(\mathrm{j}=1 \ldots 510)$ animal from $i$ hatch and $k$ sex; and $\mathrm{e}_{i j k l m}$ is the random error.

Analyses based on the likelihood ratio test $(\mathrm{P}<0.05)$ (Dobson, 1990) were carried out using additive (a), additive within sex $(\mathrm{a}(\mathrm{sex}))$, additive plus dominance deviations $(\mathrm{a}+\mathrm{d})$ and additive plus dominance deviations within sex $(\mathrm{a}+\mathrm{d}(\operatorname{sex}))$ effects. The following procedures were used in Qxpak software to check the possible effects of SNPs on the studied traits. For SNP additive effects, individuals with genotype markers ' 11 ', ' 12 ' and ' 22 ' assumed the breeding values of $\mathrm{K}_{\mathrm{AA}}, 0$, and $\mathrm{K}_{\mathrm{GG}}$, respectively. The genotypes ' 12 ' and ' 21 ' were treated identically. For SNP additive and dominance effects, individuals with genotype markers ' 11 ', '12' and '22' assumed the breeding values of $\mathrm{K}_{\mathrm{AA}}, \mathrm{K}_{\mathrm{AG}}$, and $\mathrm{K}_{\mathrm{GG}}$, respectively. Subsequently, the models were fitted within sex and the best model was chosen for each significant $(\mathrm{P}<0.05)$ trait.

\section{RESULTS AND DISCUSSION}

\section{Genotyping and SNP detection}

SNP g. 14,862T>C (ss1966531575), which is located on exon 5 of TNFSF11, and SNP g.124,883A $>\mathrm{G}$ (ss1966531593), which is located on exon 6 of $R U N X 2$, were first described in this study. SNP g.14,862T>C alters the codon TCA to CCA so the amino acid proline (nonpolar) is produced instead of serine (polar). The SNP g.124,883A>G alters the codon TCA to TCG, without changing the amino acid produced (serine).

The PCR-RFLP analysis of the RUNX2 gene (Figure 1) identified three genotypes: GG (566, 244, 198, 35, and $1 \mathrm{bp}), \mathrm{AG}(566,320,246-244,198,35$, and $1 \mathrm{bp})$, and AA (320, 246-244, 198, 35, and $1 \mathrm{bp}$ ). For the TNFSF11 gene (Figure 2), the PCR-RFLP analysis showed three genotypes: GG (863 and 98 bp), AG (863, 544, 319, and 98 bp), and AA (544, 319 , and $98 \mathrm{bp}$ ).

Genetics and Molecular Research 16 (1): gmr16019443 


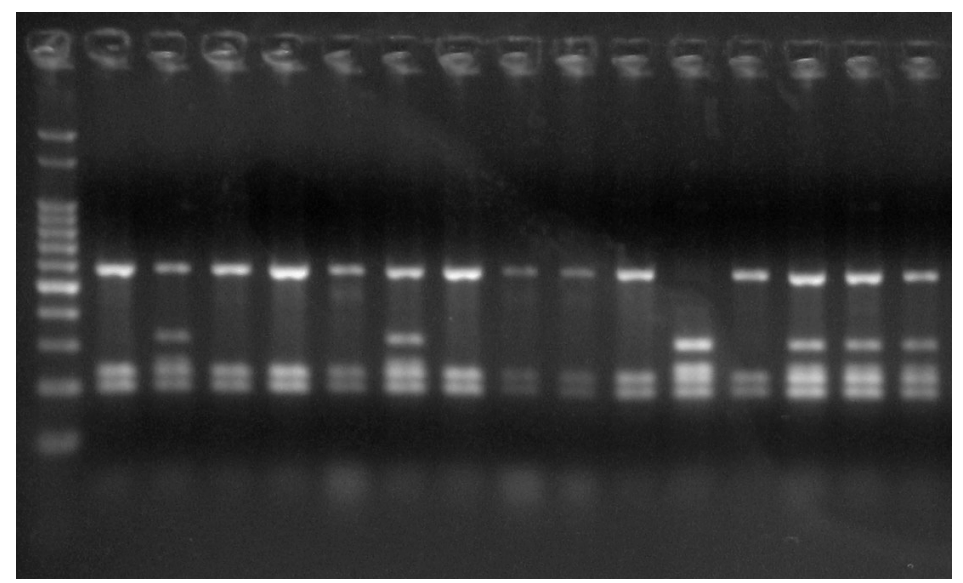

Figure 1. Genotyping by PCR-RFLP for $R U N X 2$.

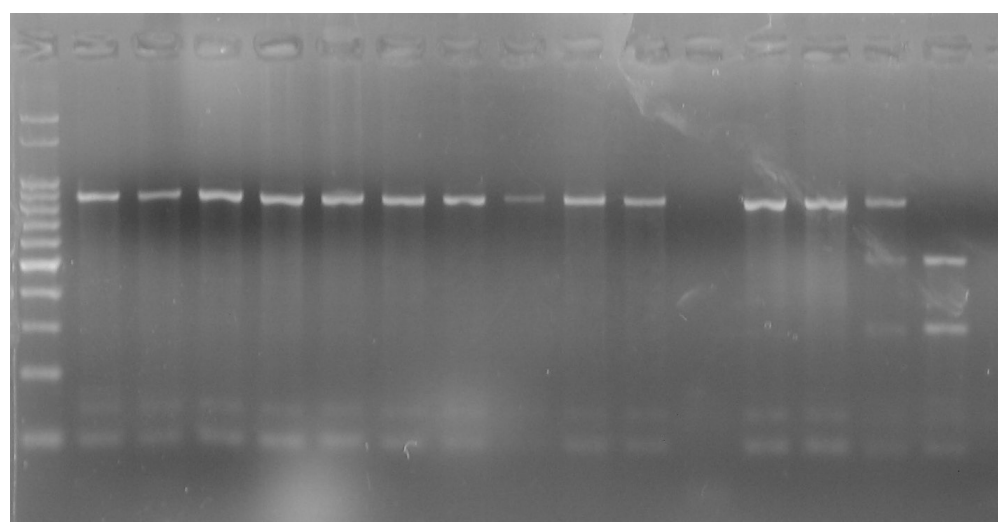

Figure 2. Genotyping by PCR-RFLP for TNFSF11.

\section{Statistical analysis}

The SNPs on TNFSF11 (g.14,862T>C) and RUNX2 (g.124,883A>G) presented three genotypic classes in the studied population (Table 1). The $\mathrm{G}$ allele had higher frequency than the A allele for $R U N X 2$ and the $\mathrm{C}$ allele had higher frequency than $\mathrm{T}$ for TNFSF11, indicating that selection in this population is close to fixation of the C allele for the SNP on TNFSF11. According to the chi-square test $\left(\chi^{2}\right)$, the population was in Hardy-Weinberg equilibrium for the SNP in RUNX2, but was not in Hardy-Weinberg equilibrium $\left(\chi^{2}=50.51 ; \mathrm{P}<0.05\right)$ for the SNP in TNFSF11.

Table 1. Genes and their SNPs, genotypes, and allele frequencies in a paternal broiler line. Number of genotyped animals $(\mathrm{N})$; number of animals per genotype, and their genotype frequencies (in parentheses) and allele frequencies.

\begin{tabular}{l|c|c|c|c|c|c}
\hline SNP/Gene & N & \multicolumn{3}{|c|}{ Genotype } & \multicolumn{2}{c}{ Allele } \\
\hline SNP $g .124,883 A>G(R U N X 2)$ & 1154 & AA & AG & GG & A & G \\
\cline { 3 - 7 } & & $165(14.3)$ & $536(46.4)$ & $453(39.3)$ & 0.3750 & 0.6250 \\
\hline \multirow{2}{*}{ SNP $g .14,862 T>C($ TNFSF11) } & \multirow{2}{*}{1264} & TT & TC & CC & T & C \\
\cline { 3 - 7 } & & $30(2.4)$ & $162(12.8)$ & $1,072(84.8)$ & 0.0878 & 0.9122 \\
\hline
\end{tabular}

Genetics and Molecular Research 16 (1): gmr16019443 
The fact that the population studied is an experimental population and was not in Hardy-Weinberg equilibrium for the SNP $g .14,862 T>C$ indicates that these allelic frequencies were modified by some factor that this population is susceptible, resulting in excessive heterozygosity. This may be because this population has been selected for performance traits, mainly for body weight, and not selected in favor of this SNP, which may be considered a limitation of this study. da Cruz et al. (2015) studied the SNPs g.102A>T (apolipoprotein B) and g. $729 \mathrm{C}>\mathrm{T}$ (adiponectin receptor 1), which are related to regulation of feed intake, fat metabolism, and protein deposition in the same experimental population of this study, and also observed that the population was not in Hardy-Weinberg equilibrium, as related in this study.

The SNPs in RUNX2 had a high frequency of heterozygotes in the studied population, reflecting high genetic variability for this particular locus. The fact that this population presented Hardy-Weinberg equilibrium for this SNP can be attributed to indirect selection that this marker is experiencing.

\section{Genetic association analysis}

Global results of the association analysis considering the best model fitted and the descriptive analyses of associated traits in this population are shown in Table 2.

Table 2. Significant associations of the SNPs in RUNX2 and TNFSF11 under different models and descriptive analyses of the associated traits.

\begin{tabular}{|c|c|c|c|c|c|c|c|}
\hline SNP/Gene & Trait & Best model fitted & $\mathrm{N}$ & Mean (SD) & CV (\%) & Min & $\operatorname{Max}$ \\
\hline \multirow{11}{*}{$\begin{array}{l}\text { g.124,883A>G } \\
(\text { RUNX2) }\end{array}$} & FI35-41 & $\mathrm{a}$ & 1147 & $1092.08(156.21)$ & 14.30 & 544.00 & 1590.00 \\
\hline & W21 & $\mathrm{a}$ & 1135 & $657.79(135.07)$ & 20.53 & 256.00 & 1034.00 \\
\hline & FBY & $\mathrm{a}$ & 1146 & $7.62(1.03)$ & 13.52 & 3.88 & 11.31 \\
\hline & BSY & $\mathrm{a}$ & 1139 & $1.41(0.25)$ & 17.73 & 0.61 & 2.42 \\
\hline & WW & $a+d$ & 1134 & $166.94(19.69)$ & 11.80 & 72.00 & 236.40 \\
\hline & TWW & $\mathrm{a}+\mathrm{d}$ & 1141 & $85.45(10.99)$ & 12.86 & 35.80 & 119.60 \\
\hline & BSW & $a(\operatorname{sex})$ & 1140 & $31.35(6.93)$ & 22.10 & 8.40 & 61.70 \\
\hline & FBW & $a(\operatorname{sex})$ & 1146 & $168.84(26.65)$ & 15.78 & 82.00 & 293.00 \\
\hline & WG35-41 & $a(\operatorname{sex})$ & 1144 & $482.79(105.92)$ & 21.94 & 128.00 & 790.00 \\
\hline & LUNW & $a(\operatorname{sex})$ & 1139 & $15.25(3.02)$ & 19.80 & 7.40 & 24.60 \\
\hline & CFW & $a+d(\operatorname{sex})$ & 1143 & $32.49(5.58)$ & 17.17 & 18.00 & 56.60 \\
\hline \multirow{4}{*}{$\begin{array}{l}g .14,862 T>C \\
(\text { TNFSF11) }\end{array}$} & HTW & $\mathrm{a}$ & 1234 & $12.42(2.16)$ & 17.40 & 6.30 & 19.70 \\
\hline & BW & $\mathrm{a}+\mathrm{d}(\operatorname{sex})$ & 1258 & $47.66(3.72)$ & 7.80 & 37.40 & 61.80 \\
\hline & WG35-41 & $\mathrm{a}+\mathrm{d}(\operatorname{sex})$ & 1251 & $490.14(106.40)$ & 21.71 & 158.00 & 802.00 \\
\hline & FC35-41 & $a+d(\operatorname{sex})$ & 1251 & $2.31(0.45)$ & 19.48 & 1.42 & 4.95 \\
\hline
\end{tabular}

$\mathrm{P}<0.05 . \mathrm{N}=$ number of observations, means and respective standard deviation $(\mathrm{SD}), \mathrm{CV}(\%)=\mathrm{coefficient}$ of variation, $\mathrm{Min}=$ minimum values observed, $\mathrm{Max}=$ maximum values observed. Traits: feed intake from 3 to 41 days (FI35-41), feathers and blood yield (FBY), breast skin yield (BSY), wing weight (WW), thigh wing weight (TWW), breast skin weight (BSW), feathers and blood weight (FBW), weight gain from 35 to 41 days (WG35-41), lung weight (LUNW), chilled femur weight (CFW), body weight at 21 days (W21), body weight at birth (BW), heart yield (HTY), heart weight (HTW), and feed conversion 35-41 days (FC35-41). Weights were measured in grams and yield in percentages (\%). The letters indicate the SNP effects: a, additive effects; a(sex), additive effects within sex; $a+d$, additive plus dominance effects; $a+d(s e x)$, additive plus dominance effects within sex.

The effects of the SNPs in RUNX2 and TNFSF11 that were significantly associated $(\mathrm{P}<0.05)$ with several production traits in the TT Reference Population are shown in Tables $3,4,5$, and 6 . The additive plus dominance effects of $R U N X 2$ within sex were significant for chilled femur weight (CFW) and birth weight (BW), while two performance traits (weight gain from 35 to 41 days and feed conversion from 35 to 41 days) were significant for TNFSF 11 (Table 3).

Genetics and Molecular Research 16 (1): gmr16019443 
Table 3. Additive plus dominance deviation effects within sex from the association analysis of $R U N X 2$ and TNFSF11 and production traits.

\begin{tabular}{l|c|c|c|c|c|c|c}
\hline SNP/Gene & Trait & a (SE) Male & a (SE) Female & d (SE) Male & d (SE) Female & P value & LR \\
\hline g. $124,883 A>G(R U N X 2)$ & CFW & $0.48(0.31)$ & $0.19(0.27)$ & $1.31(0.39)$ & $-0.13(0.36)$ & 0.014 & 12.39 \\
\hline & BW & $0.71(0.31)$ & $0.68(0.31)$ & $-0.68(0.41)$ & $-0.18(0.42)$ & 0.016 & 12.13 \\
\hline g.14,862T>C (TNFSF11) & WG35-41 & $23.64(10.92)$ & $-4.32(10.92)$ & $-42.89(14.22)$ & $-3.91(14.68)$ & 0.044 & 9.78 \\
\hline & FC35-41 & $-0.11(0.04)$ & $-0.01(0.04)$ & $0.23(0.06)$ & $-0.03(0.06)$ & 0.003 & 15.62 \\
\hline
\end{tabular}

Additive effects: a, dominance deviations effects; $d$, standard errors in parentheses. LR: Likelihood-ratio test $(\mathrm{P}<$ 0.05). Traits: chilled femur weight (CFW), body weight at birth (BW), weight gain from 35 to 41 days (WG35-41), and feed conversion 35-41 days (FC35-41). Weights were measured in grams and yields in percentages (\%).

For the $R U N X 2$ gene, genetic association with additive plus dominance deviation effects within sex was found only for chilled femur weight in males (Table 3). Although this trait is related to bone integrity, we observed genetic correlation of this trait only with femur length in a previous study (Grupioni et al., 2015).

Traits related to animal performance with significant $(\mathrm{P}<0.05)$ additive plus dominance deviation effects within sex for the allelic substitution of $\mathrm{T}>\mathrm{C}$ in TNFSF11 were favorable in males for all traits shown in Table 3. Males presented favorable additive effects for performance traits (BW, WG35-41, and FC35-41). However, unfavorable dominance effects were significant for WG35-41 and FC35-41 in males. Depending on the intralocus relationship, these SNPs can have an important influence on those performance traits. However, it is the genic combination intralocus effect that shows the dominance relationship. The increase in $\mathrm{G}$ allele frequency for $R U N X 2$ and $\mathrm{C}$ allele frequency for TNFSF11 contributes to improving the performance of these phenotypic traits, and their expression also depends on the genetic combination of these alleles.

Results from the association fitting the additive plus dominance effects $(\mathrm{a}+\mathrm{d})$ are shown in Table 4. Feathers and blood weight (FBW), thigh wing weight (TWW), and wing weight (WW) were associated with the RUNX2 SNP only when this model was fitted. The observed dominance degree was classified as overdominance for WW and partial for FBW and TWW.

Table 4. Additive plus dominance deviation effects and dominance degree from the association analysis between $R U N X 2$ and production traits.

\begin{tabular}{l|c|c|c|c|l}
\hline Trait & $\mathrm{a}(\mathrm{SE})$ & $\mathrm{d}(\mathrm{SE})$ & P value & LR & Dominance degree $(\mathrm{d} / \mathrm{a})$ \\
\hline FBW & $3.31(1.18)$ & $1.73(1.48)$ & 0.020 & 7.80 & Partial \\
\hline TWW & $1.07(0.46)$ & $0.98(0.57)$ & 0.039 & 6.49 & Partial \\
\hline WW & $1.60(0.73)$ & $1.64(0.91)$ & 0.043 & 6.29 & Overdominance
\end{tabular}

Additive effects, a; dominance deviations effects, d; standard errors in parentheses; dominance degree, d/a. LR: Likelihood-ratio test $(\mathrm{P}<0.05)$. Traits: feathers and blood weight $(\mathrm{FBW})$, thigh wing weight $(\mathrm{TWW})$, wing weight (WW). Weights measured in grams.

Regarding the additive plus dominance deviation effects for the $g \cdot 124,883 A>G$ allelic substitution in the $R U N X 2$ gene, significant $(\mathrm{P}<0.05)$ effects were observed for FBW, TWW, and WW traits (Table 4). The amount of blood and feathers may influence the increase in waste and consequently decrease the final weight of meat produced. Regarding the TW and WW wing traits, direct selection for the $\mathrm{G}$ allele may not be efficient in phenotypic expression of these traits because part of the dominance deviation relationship presented similar magnitude values to the additive effects (Table 4). Dominance deviation effects are non-linear associations

Genetics and Molecular Research 16 (1): gmr16019443 
with non-additive effects owing to the interaction between alleles at the same locus. According to Crnokrak and Rpoff (1995), the study of non-additive gene action of dominance is important because it is part of the phenotypic expression and may affect the heritability estimates of traits.

The additive effects within sex with significant associations between production traits are shown in Table 5. The RUNX2 SNP had a positive additive effect only in males for the weight gain from 35 to 41 days (WG35-41), FBW, lung weight (LUNW), and breast skin weight (BSW) traits. The SNP in the TNFSF11 gene was not influenced by the sex of the broilers.

Table 5. Additive effects within sex from the association analysis between $R U N X 2$ and production traits.

\begin{tabular}{l|c|c|c|c|c}
\hline SNP/Gene & Trait & a (SE) Male & a (SE) Female & P value & LR \\
\hline \multirow{3}{*}{.124,883A>G(RUNX2) } & WG35-41 & $14.48(5.71)$ & $4.72(5.28)$ & 0.034 & 6.72 \\
\cline { 2 - 7 } & LUNW & $0.41(0.17)$ & $0.12(0.15)$ & 0.049 & 6.04 \\
\cline { 2 - 7 } & BSW & $0.82(0.42)$ & $0.74(0.39)$ & 0.040 & 6.21 \\
\hline
\end{tabular}

Additive effects, $\mathrm{a}$; standard errors in parentheses. LR: Likelihood-ratio test $(\mathrm{P}<0.05)$. Traits: weight gain from 35 to 41 days (WG35-41), feathers and blood weight (FBW), lung weight (LUNW), breast skin weight (BSW). Weights were measured in grams and yields as percentages (\%).

The association analyses using the additive model effects for the SNPs in $R U N X 2$ and TNFSF 11 are shown in Table 6. The allelic substitution of the SNP $g .124,883 A>G$ in the $R U N X 2$ gene significantly influenced $(\mathrm{P}<0.05)$ the following performance traits: body weight at 21 days (W21), feed intake from 3 to 41 days (FI35-41), feathers and blood yield (FBY) and breast skin yield (BSY). The allelic substitution of SNP g.14,862 T>C in the TNFSF11 gene had a negative effect on HTW $(-0.21 \pm 0.10)$. This SNP also presented suggestive associations $(\mathrm{P}<0.10$; not shown) with abdominal fat weight (AFW) and its yield (AFY), where $\mathrm{T}$ to $\mathrm{C}$ allelic substitution could be favorable to reduce fat deposition.

Considering the additive effects within sex (Table 5), it can be stated that the selection for allelic substitution in RUNX2 (A> G) for the WG35-41, FBW, LUNW, and BSW traits will be effective only in males. The selection of the RUNX2 SNP favoring the $\mathrm{G}$ allele could result in broilers with higher phenotypic performance for those traits. In addition, the $\mathrm{G}$ allele also increased BSW (Table 5) and breast skin yield, which are traits related to fat deposition. Jennen et al. (2005) identified a QTL (Quantitative Trait Locus) region where the RUNX2 gene is mapped, associated with body weight at 49 days of age, abdominal fat, and abdominal fat percentage.

Table 6. Additive effects (a) from the association analysis of RUNX2 and TNFSF11 and production traits.

\begin{tabular}{l|c|c|c|c}
\hline SNP/Gene & Trait & a (SE) & P value & LR \\
\hline \multirow{3}{*}{.124,883A>G(RUNX2) } & W21 & $7.84(3.59)$ & 0.032 & 1.24 \\
\cline { 2 - 5 } & FI35-41 & $13.16(6.48)$ & 0.042 & 4.10 \\
\cline { 2 - 5 } & FBY & $0.09(0.04)$ & 0.043 & 4.08 \\
\cline { 2 - 5 } & BSY & $0.02(0.01)$ & 0.055 & 3.66 \\
\hline g.14,862T>C (TNFSF11) & HTW & $-0.21(0.10)$ & 0.028 & 4.86 \\
\hline
\end{tabular}

Additive effects, a; standard errors in parentheses. LR: Likelihood-ratio test $(\mathrm{P}<0.05)$. Traits: weight at 21 days (W21), feed intake from 35 to 41 days (FI35-41), feathers and blood yield (FBY), breast skin yield (BSY), heart weight $(\mathrm{HTW})$. Weights were measured in grams and yields as percentages $(\%)$.

Moderate associations ( $\mathrm{P}<0.10$; not shown) found with AFW and AFY traits suggested that the $\mathrm{C}$ allele of the TNFSF11 SNP could reduce carcass fat deposition. These results indicate that this marker could be used in selection to reduce abdominal fat in broilers, after appropriate

Genetics and Molecular Research 16 (1): gmr16019443 
validation. Park et al. (2006) identified a QTL region associated with abdominal fat in broilers, where the TNFSF11 gene is mapped. Moreover, Fornari et al. (2014) found significant $(\mathrm{P}<$ $0.05)$ associations between the osteoprotegerin gene (TNFRSF11B) and AFW and AFY traits in the same population used in this study. The TNFRSF $11 B$ gene acts as a decoy receptor of the TNFSF11 gene (Boyle et al., 2003). Therefore, TNFRSF11B/TNFRSF11 balance signaling may be directly involved in fat deposition. Most likely, this mechanism is mediated by adiponectin hormone (ADIPOQ). According to Luo et al. (2006), ADIPOQ hormone inhibits TNFRSF11B gene expression in osteoblasts and stimulates TNFRSF11 gene expression in humans.

da Cruz et al. (2015), studying a SNP in the adiponectin receptor 1 gene (ADIPOR1) in the same population studied here, found an additive effect $(\mathrm{P}=0.001 ;-0.0016 \pm 0.0005)$ with the breast skin yield trait and dominance effect $(\mathrm{P}=0.014 ; 20.47 \pm 8.25)$ with the FI35-41 trait. In the present study, additive effects were also found for RUNX2 for FI35-41 and BSY traits (Table 6).

Further studies are required to elucidate the possible causes of the associations found in this study since the direct effect of the mutations, interactions with other genes, and/or the linkage disequilibrium between the SNPs and causative mutations resulting from an indirect effect (Fornari et al., 2014) may be responsible for the associations of the two SNPs studied here with several traits in this broiler population.

\section{CONCLUSIONS}

Despite the functional importance of the RUNX2 and TNFSF11 genes in bone metabolism, associations with bone integrity-related traits were found only for chilled femur weight and the $R U N X 2$ gene. However, the chilled femur weight is not a good parameter for use as a selection criterion in this population. Furthermore, associations of $R U N X 2$ and TNFSF 11 were identified with performance, carcass, and organ traits and could be used in the selection process to improve performance and carcass composition traits of broilers, after appropriate validation.

Although the limiting factor that TNFSF11 (g.14,862T>C) is not in Hardy-Weinberg equilibrium and the negative pleiotropic effects involving important traits compromise their potential use in marker-assisted selection, it is important to emphasize the relevance of candidate gene studies to improve our understanding of the genetic architecture control of traits involved in broiler production.

\section{Conflicts of interest}

The authors declare no conflict of interest.

\section{ACKNOWLEDGMENTS}

The authors would like to acknowledge Embrapa (Empresa Brasileira de Pesquisa Agropecuária) Swine and Poultry National Research Center for providing the datasets used in this research. N.V. Grupioni was supported by a fellowship from Coordenação de Aperfeiçoamento de Pessoal de Nível Superior (CAPES)/EMBRAPA. N.B. Stafuzza and A.B. Carvajal were supported by fellowships from CAPES. D.P. Munari was supported by the Productivity Researcher Fellowship from CNPq. We would like to thank Vicky Lilge Kawski from EMBRAPA for her support with mineral analysis.

Genetics and Molecular Research 16 (1): gmr16019443 


\section{REFERENCES}

Bessei W (2006). Welfare of broilers: a review. Worlds Poult. Sci. J. 62: 455-466. http://dx.doi.org/10.1079/WPS2005108

Boyle WJ, Simonet WS and Lacey DL (2003). Osteoclast differentiation and activation. Nature 423: 337-342. http:// dx.doi.org/10.1038/nature01658

Crnokrak P and Rpoff DA (1995). Dominance variance: associations with selection and fitness. Heredity 75: 530-540. http://dx.doi.org/10.1038/hdy.1995.169

da Cruz VAR, Schenkel FS, Savegnago RP, Grupioni NV, et al. (2015). Association of Apolipoprotein B and Adiponectin Receptor 1 genes with carcass, bone integrity and performance traits in a paternal broiler line. PLoS One 10: e0136824. http://dx.doi.org/10.1371/journal.pone.0136824

Danbury TC, Weeks CA, Chambers JP, Waterman-Pearson AE, et al. (2000). Self-selection of the analgesic drug carprofen by lame broiler chickens. Vet. Rec. 146: 307-311. http://dx.doi.org/10.1136/vr.146.11.307

Dransfield E and Sosnicki AA (1999). Relationship between muscle growth and poultry meat quality. Poult. Sci. 78: 743746. http://dx.doi.org/10.1093/ps/78.5.743

Dobson AJ (1990). An introduction to generalized linear models. 2nd ed. Chapman and Hall, New York.

Fornari MB, Zanella R, Ibelli AM, Fernandes LT, et al. (2014). Unraveling the associations of osteoprotegerin gene with production traits in a paternal broiler line. Springerplus 3: 682. http://dx.doi.org/10.1186/2193-1801-3-682

Genetics and Home Reference (2013). Your guide to understanding genetic conditions. Available at [https://ghr.nlm.nih.gov].

González-Cerón F, Rekaya R and Aggrey SE (2015). Genetic analysis of bone quality traits and growth in a random mating broiler population. Poult. Sci. 94: 883-889. http://dx.doi.org/10.3382/ps/pev056

Grupioni NV, Cruz VA, Stafuzza NB, Freitas LA, et al. (2015). Phenotypic, genetic and environmental parameters for traits related to femur bone integrity and body weight at 42 days of age in a broiler population. Poult. Sci. 94: 2604-2607. http://dx.doi.org/10.3382/ps/pev257

Jennen DG, Vereijken AL, Bovenhuis H, Crooijmans RM, et al. (2005). Confirmation of quantitative trait loci affecting fatness in chickens. Genet. Sel. Evol. 37: 215-228. http://dx.doi.org/10.1186/1297-9686-37-3-215

Julian RJ (1998). Rapid growth problems: ascites and skeletal deformities in broilers. Poult. Sci. 77: 1773-1780. http:// dx.doi.org/10.1093/ps/77.12.1773

Kammerer M, Gutzwiller S, Stauffer D, Delhon I, et al. (2013). Estrogen Receptor a (ERa) and Estrogen Related Receptor a (ERRa) are both transcriptional regulators of the Runx2-I isoform. Mol. Cell. Endocrinol. 369: 150-160. http:// dx.doi.org/10.1016/j.mce.2013.01.024

Lamont SJ, Deeb N and Zhou H (2004). Genes for skeletal strength in poultry. Anim. Ind. Rep 650: 94.

Li H, Deeb N, Zhou H, Mitchell AD, et al. (2003). Chicken quantitative trait loci for growth and body composition associated with transforming growth factor-beta genes. Poult. Sci. 82: 347-356. http://dx.doi.org/10.1093/ps/82.3.347

Locatelli V and Bianchi VE (2014). Effect of GH/IGF-1 on bone metabolism and osteoporosis. Int. J. Endocrinol. 2014: 235060. http://dx.doi.org/10.1155/2014/235060

Luo XH, Guo LJ, Xie H, Yuan LQ, et al. (2006). Adiponectin stimulates RANKL and inhibits OPG expression in human osteoblasts through the MAPK signaling pathway. J. Bone Miner. Res. 21: 1648-1656. http://dx.doi.org/10.1359/ jbmr.060707

Neville BW, Damm DD, Allen CM and Bouquo J (2002). Oral and maxillofacial pathology. 2nd ed. WB Saunders, Philadelphia.

Otto F, Kanegane H and Mundlos S (2002). Mutations in the RUNX2 gene in patients with cleidocranial dysplasia. Hum. Mutat. 19: 209-216. http://dx.doi.org/10.1002/humu.10043

Park HB, Jacobsson L, Wahlberg P, Siegel PB, et al. (2006). QTL analysis of body composition and metabolic traits in an intercross between chicken lines divergently selected for growth. Physiol. Genomics 25: 216-223. http://dx.doi. org/10.1152/physiolgenomics.00113.2005

Pérez-Enciso M and Misztal I (2004). Qxpak: a versatile mixed model application for genetical genomics and QTL analyses. Bioinformatics 20: 2792-2798. http://dx.doi.org/10.1093/bioinformatics/bth331

Ragognetti BNN, Stafuzza NB, Silva TBR, Chud TCS, et al. (2015). Genetic parameters and mapping quantitative trait loci associated with tibia traits in broilers. Genet. Mol. Res. 14: 17544-17554. http://dx.doi.org/10.4238/2015. December.21.27

Rath NC, Huff GR, Huff WE and Balog JM (2000). Factors regulating bone maturity and strength in poultry. Poult. Sci. 79: 1024-1032. http://dx.doi.org/10.1093/ps/79.7.1024

Untergasser A, Nijveen H, Rao X, Bisseling T, et al. (2007). Primer3Plus, an enhanced web interface to Primer3. Nucleic Acids Res. 35: W71-4. http://dx.doi.org/10.1093/nar/gkm306

Usui M, Xing L, Drissi H, Zuscik M, et al. (2008). Murine and chicken chondrocytes regulate osteoclastogenesis by

Genetics and Molecular Research 16 (1): gmr16019443 
producing RANKL in response to BMP2. J. Bone Miner. Res. 23: 314-325. http://dx.doi.org/10.1359/jbmr.071025 Venturini GC, Stafuzza NB, Cardoso DF, Baldi F, et al. (2015). Association between ACTA1 candidate gene and performance, organs and carcass traits in broilers. Poult. Sci. 94: 2863-2869. http://dx.doi.org/10.3382/ps/pev285

Vincze T, Posfai J and Roberts RJ (2003). NEBcutter: A program to cleave DNA with restriction enzymes. Nucleic Acids Res. 31: 3688-3691. http://dx.doi.org/10.1093/nar/gkg526

Zhou H, Mitchell AD, McMurtry JP, Ashwell CM, et al. (2005). Insulin-like growth factor-I gene polymorphism associations with growth, body composition, skeleton integrity, and metabolic traits in chickens. Poult. Sci. 84: 212219. http://dx.doi.org/10.1093/ps/84.2.212

Zhou H, Deeb N, Evock-Clover CM, Mitchell AD, et al. (2007). Genome-wide linkage analysis to identify chromosomal regions affecting phenotypic traits in the chicken. III. Skeletal integrity. Poult. Sci. 86: 255-266. http://dx.doi. org $/ 10.1093 / \mathrm{ps} / 86.2 .255$

\section{Supplementary material}

Table S1. Production traits evaluated from the TT Reference Population database.

Table S2. PCR primer sequences, GenBank accession No. of RUNX2 and TNFSF11 gene sequences, and amplicon size. 